\title{
Developing Sekayu Local Culture-Based Descriptive Texts
}

\author{
Lumei Haryanti', Rita Inderawati ${ }^{2}$, Eryansyah ${ }^{3}$ \\ Department of English Education, Sriwijaya University, Palembang, Indonesia 1,2,3 \\ Email: eryansyah@unsri.ac.id ${ }^{3}$
}

Submitted: $20 / 06 / 2020$

Revised: 03/11/2020

Accepted: 08/01/2021

E-ISSN : $2579-4574$

P-ISSN : 2549-7359

\begin{abstract}
The study aimed to find out the validity, practicality, and potential effect of the developed reading materials with local culture based descriptive texts. The development research consisted of analysis, design, evaluation and revision was used. Then, formative evaluation proposed by Tessmer (1993) was also used. In order to review the product, there were 2 experts in expert review, 3 students involved in one-to-one, 9 students involved in small group which were given the reading materials and 18 students involved in field test. The questionnaires and a test were used in order to collect the data. The results showed that the developed product was valid after being evaluated in expert review which was categorized as highly valid. The product was also practical after being evaluated in one-toone and small group which were categorized as very highly practical. Then, the reading assessment also could be categorized as effective since there were 12 students reached the minimum mastery criterion
\end{abstract}

Keywords: development research, local culture, descriptive texts.

https://ojs.unm.ac.id/eralingua

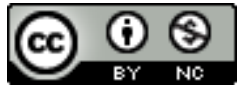

This work is licensed under a Creative Commons Attribution-NonCommercial 4.0 International License 


\section{INTRODUCTION}

Reading comprehension is not a single step or an easily acquired skill. It is a complex interaction among automatic and strategic cognitive processes that enables the reader to create a mental representation of the text (Broek \& Espin, 2012).As readers mature in their comprehension skills, they are able to progress efficiently from the stage of learning to read to the ultimate goal of reading to learn (Yovanoff, Duesbery, Alonzo, \& Tindal, 2005). Furthermore, according to Prado and Plourde (2005), the foundation of reading comprehension is word identification and decoding. As individuals get better at these skills and are able to read words, they have to move into learning the actual meanings of the words they are reading. Knowing and understanding what is being read is the key to comprehension. Without all of these skills, one cannot comprehend properly and, therefore, not read properly.

One of the most frequent topics in the EFL reading classroom today is the issue of reading comprehension. Kasim and Raisha (2017) have mentioned the necessity to comprehend texts by stating that reading means comprehending. In this sense, few teachers would deny that the ability to comprehend English texts is probably one of the aspects which are most required by EFL students. However, in reality, many EFL students are still struggling to overcome their reading comprehension problems. Davoudi and Yousefi (2015) have listed a number of EFL learners reading difficulties and problems such as deficits in vocabulary knowledge and background knowledge, problems with grammatical knowledge and also poor reading strategies which is very important to reduce the difficulties (Samad, Jannah \&Fitriani, 2017)

Furthermore, reading comprehension problems have been a popular issue in EFL teaching-learning settings for a long time. Numerous studies have shown that most EFL students often have difficulties in comprehending English texts (Kasim and Raisha, 2017). Chen and Chen (2015) have said that about 52\% of adults with L2 reading comprehension problems had difficulties in learning a foreign language. In this sense, there are several reading problems which may be encountered by EFL students. First, they are probably not keen on reading L2 literature because they have to work hard to comprehend it. Second, studies mention several common problems in the EFL reading classroom such as insufficient vocabulary, problems understanding linguistic complexity including lexical and syntactic knowledge, language inaccessibility, poor reading skills and lack of schemata (Alyousef, 2006; Fitriani, 2014; Rahman, 2004).

Internationally, the issue of reading also existed for Indonesian students. PISA a program conducted by Organization for Economic Cooperation and Development (OECD) which tests critical thinking in math, science, and reading to 15-year-old students in 72 countries, regardless of grade, achievement, and socioeconomic status reported some unsatisfactory results of Indonesian young adults' reading literacy. In 2015, Indonesia ranked 62nd, a slight improvement compared to 2013. Indonesian students ranked the second-lowest in the 2013 PISA ranking (71), yet worse than their ranking in 2009, when Indonesia ranked 57th. However, the mean score of reading is still low which is 397 while the OECD mean score was 493 
(OECD, 2018). In addition, based on survey data of the English Proficiency Index, Indonesia ranked 39th out of 80 countries in 2017 with the score 52.15 and it is categorized as low proficiency (EF EPI, 2017). These data revealed that there were problems of the Indonesian students both in reading literacy and in English proficiency.

In addition to the problem in reading literacy discussed above, the reading habit of students in Indonesia, especially in South Sumatera is still apprehensive (Sari, 2016). The availability of libraries in Indonesia is also one of the causes of why it happened (Diem, 2012). The study conducted by Diem (2012) found that in South Sumatra, there have been only $30 \%$ of high school libraries that satisfy the national standard. It means that the rests are still lamentable and out of expectations. Therefore, many students do not want to read not because they cannot read, but because of the book collection in the school library. This finding suggests that having a good library and adequate book collection are much needed in promoting reading habits.

Concerning what happened about the reading habit as mentioned above, the results of some studies showed the fact that reading comprehension is still an issue in Indonesia. For instance, Masduqi (2014) found that students are not willing to read their reading textbooks although they realized their usefulness. He argues that this lack of interest is due to the students' inadequate prior knowledge, inability to comprehend the reading texts, and complex structure of the textbooks. This study is confirmed by the findings of the studies conducted by Rukmini (2004) and Firmanto (2005). Rukmini (2004) who conducted her study in Palembang found that new university students lack interest in reading classes since they are not familiar with explanation and discussion genres in reading texts at the tertiary level. It is because the genres in most secondary school textbooks are anecdotes and descriptive texts (Rukmini, 2004). In line with this, the study conducted by Firmanto (2005) found that reading was considered a boring and stressful activity because of some factors such as unsuitable texts (e.g., due to the text length or unfamiliar vocabularies), teachers scarcity in employing pre-reading activities (e.g., explaining some difficult words or activating the students prior knowledge), and monotonous post-reading activities (e.g., answering questions based on the texts and retelling the texts). The problems faced by the students clearly show that the failure of teaching reading is not only on the teacher but also on the materials given. It can be concluded that reading textbooks without any prior knowledge will be challenging for students. In addition, if teachers give unfamiliar topics for students, the students may have difficulty to comprehend the text and they may also get bored during reading activities.

The problems in English reading also existed at SMP Negeri 2 Sanga Desa. Based on the result of observation conducted by the writer, it was found that the English teachers of SMP Negeri 2 Sanga Desa only used one English textbook in teaching reading. The texts provided were also not about local culture where it was really needed to improve students' knowledge about their own culture and preserve what they have. Therefore, many students did not seem interested in reading activities. According to Peterson and Ostendorf (2006), teachers need to 
find material at a variety of levels, since students need different texts to read independently and with help from the teacher. However, finding appropriate reading materials is difficult and time-consuming, and teachers are often forced to rewrite texts by themselves to suit the varied needs of their students.

The result of the writer's observation suggests that appropriate materials are needed in order to avoid the boredom of the students when they read the text. Students often feel bored when they read unfamiliar topics. It is also difficult for students to comprehend the text. Based on the eighth grade syllabus, the students must learn three genres of texts. Sopian, Inderawati, and Petrus (2019) state that the skill of reading is available the 2013 Curriculum, the eighth graders of junior high school are going to learn some English texts which include a report, recount, and narrative which have to be mastered by them. Descriptive text is a story for telling how to describe particular person, thing, or place. Emilia and Christie (2013) argue that learning descriptive genre is essential in order student can describe vivid and proper information. In learning descriptive genre, students can use textbooks, as it plays a key role in teaching and learning process (Presnyakova, 2011). However, the English textbook should provide a good example of descriptive texts for students to get a good understanding of what the descriptive genre is. Presnyakova (2011) states that students' success in school depends to a great extent on their understanding of the texts, and this understanding is influenced 'by a variety of features that characterize the nature of text. Thus, the descriptive texts in textbook should be analyzed in order to look whether texts provide an appropriate example to the students, based on the criteria of the descriptive text, such as its schematic structure, purpose and linguistic features.

Dealing with the issue of the instructional reading materials, the writer expects that the English textbook used by the teachers of SMP Negeri 2 Sanga Desa provides the local culture as the reading materials in which it can give more knowledge and enhance the students' interest in learning English. Moreover, the local culture reading materials are also needed to every school which have the similar problem with what has described above. Kirkpatrick (2008) states that Indonesian students tend to communicate in English when discussing local cultural information with foreigners (English speakers). He suggests that an approach was sensitive to local culture texts in teaching English reading, especially for EFL students will make the students motivated because local culture texts involve the topics which the students are familiar. Moreover, Malone (2013) argues that the alternative way that can be used by EFL teacher to help the students become lifelong readers is by providing the students with information or reading materials which are relevant to students' life, heritage and culture, such as the story from the local content dealing with local people, object and events.

However, even though the use of local culture based material is highly recommended and stated in the curriculum, the number of local culture based material is still limited in Indonesia, even many schools do not have English text book containing local culture. According to Pitaloka (2014), there were some problems in the English text-books used in Indonesia which is concerned with the limitation of local culture-based materials and the inappropriate readability of the 
texts used. Furthermore, the study conducted by Monica (2016) showed that through the instructional analysis, the English teachers of SMP Negeri 11 Lubuklinggau only used one English course book that lack of local content-based material, additionally, that textbook was also offering the reading comprehension test which providing the descriptive texts with the readability level was irrelevant to the students' reading level as indicated at level 3. As Elviana, Inderawati, and Mirizon (2020) state that the objective of teaching English as stated in the national curriculum is achieving communicative competence. To achieve communicative competence, culture is the basis of communication since the meaning conveyed in the language used depends on a society where they live and the communication is delivered through language. In other words, teaching language is never done without culture.

The results of analyses above clearly reveal the number of the instructional reading materials in SMP N 2 Sanga Desa containing local culture needs to be added in order to promote and expose more the local culture towards the students' prior knowledge. In this study, the writer focuses on the traditional food and places related to the famous local culture which is originally from Sekayu that are expected can be utilized effectively as instructional reading materials in EFL teaching. The information about local culture itself will be described clearly into a passage based on the eighth graders syllabus and reading level since many students are not familiar with their own culture in term of famous local culture of Sekayu. Therefore, in order to make the students easily comprehend the reading text, the writer hopes that these reading materials will enhance the students' reading comprehension and improve the students literacy. Besides, it is also expected that the students will develop their reading habit into their daily activities and enrich their local culture knowledge as become the issues discussed before.

In addition, by providing the local culture based instructional reading materials in the form of descriptive text, the writer expects the information about Sekayu culture can be exposed effectively to the students and will not be vanished from its existence as a part of precious local culture of Indonesia in this globalization era. From the explanations above, it can be concluded that the objectives of this study were to to find out the validity, practicality, and potential effect of the developed reading materials with local culture based descriptive texts for the Eighth Graders of SMP Negeri 2 Sanga Desa.

\section{RESEARCH METHOD}

In this study, the writer used development research method to develop instructional reading materials with local culture based descriptive text. It was proposed by Akker (1999) which consisted of analysis, design, evaluation, and revision. On the analysis phase, the writer analyzed the developed local culture based descriptive texts based on the students' need, reading level, and curriculum. Meanwhile, on the design phase, the writer designed the developed local culture based descriptive text consisting of reading passages and exercises in the form of paper-based design. Next, for the evaluation phase, in this study, the writer used formative evaluation model proposed by Tessmer (1993) consisted of self- 
evaluation, expert review, one-to-one evaluation, small group evaluation, and field test.

In expert review phase, there were 2 experts evaluating the developed product in terms of content and construct. Moreover, students were also involved in evaluating the developed product. There were 3 students participating in one-toone evaluation (1 student for each category of English proficiency level, i.e.: low, medium, and high English proficiency which were selected based on their English score), 9 students participating in small group evaluation (3 students for each category of English proficiency level, i.e.: low, medium, and high English proficiency), and 18 students of a real class participating in field test.

To determine the criteria of the product which were its validity, practicality, and effectiveness, the questionnaires and reading comprehension test were used. The questionnaires were adapted from Sari (2016) who had tried it out to the students. The questionnaires consisted of 15 items. To determine the validity and practicality level of the product, the average score of the obtained scores from the two experts' judgment through questionnaires (for validity) and from students through questionnaire (for practicality) was calculated and interpreted as follows:

Table 1. Validity and Practicality Categorization

\begin{tabular}{ll}
\hline Average score & Category \\
\hline $3.26-4.00$ & Very high \\
\hline $2.51-3.25$ & High \\
\hline $1.76-2.50$ & Low \\
\hline $1.00-1.75$ & Very low \\
\hline
\end{tabular}

Source: Modified from Kubiszyn\&Borich (1993)

Meanwhile, to determine the effectiveness of reading comprehension test, the students' scores of reading comprehension test in the field test were correlated to the score of standardized test from Stark which was given in order to measure the students' reading level by using Pearson Product Moment. Then, the scores of each reading aspects (categorized as literal, inferential, and vocabulary) in reading comprehension test were also compared partially to which included in reading level test. Moreover, the reliability, items validity, index of difficulty, and discrimination index of the test were also measured by using SPSS version 22.

However, the time became the limitation of this study. Since the students only have two meetings (each meeting take 80 minutes) to study the reading materials given, they felt difficulty to comprehend the text well in which it is about the culture. They put their comments about having the limit time while doing the exercise. The high performance required by competitive conditions forces organizations and directors to use time effectively and stipulates the search to control time (Alay and Kocak, 2003). Therefore, the writer prepares to have sufficient time to explain the materials and to let the students doing the exercise in the future. 


\section{RESULTS AND DISCUSSION}

\section{Analysis Phase}

\section{Instructional Analysis}

There are some steps the writer did before developing the reading materials. Firstly, the descriptive text available in English textbook entitled "When English Rings a Bell" was analyzed which was used by students in teaching and learning activity. From the studentsEnglish textbook, there were 2 descriptive texts found entitled "I am proud of Indonesia" and "My New Backpack" which have the readability level above 11 . Then, many ungrammatical sentences were found in reading text. Therefore, it can be said that the total of the descriptive texts in the students' English textbook was not appropriate for the eighth-grade students. In addition, the writer analyzed the curriculum 2013 to determine the learning objectives for the developed materials. In short, after the English textbook which is used commonly by teacher, the writer developed the reading materials based on the students' need and the students' reading level.

Students' Needs Analysis

In this phase, the aim of students' needs analysis was intended to obtain information about students' needs in terms of reading material. To know students' reading achievement, the questionnaire was used to find out some information related to the teaching and learning process in a reading activity in the classroom. The questionnaire consisted of twenty questions. Then, it was administered to 30 eighth grade students.

The results of the analysis are described as follows.

1. There were $66.66 \%$ of 30 students felt difficult about the language used in the reading text since they have difficulty in comprehending the text (70\%). It was caused that of reading text in their textbook was uninteresting (76.66\%).

2. The studentsopinion towards the content of the reading text that they were interested in reading text containing the local culture $(80 \%)$ since they were really familiar with local culture in Sekayu (73.33\%).

3. The students felt that it is important to know the local culture especially in Sekayu (73.33\%) and it is important for a teacher to give local content reading materials while studying (73.33\%) especially for reading local culture of Sekayu (66.66\%)

4. The students also claimed that their English teacher rarely gives them local culture reading materials (70\%) so that most students do not know about the culture from their cities (66.66).

Based on the interpretation of the result of students' needs analysis, it can be concluded that local culture reading materials (i.e. descriptive texts about the culture of Sekayu) were needed to be developed. It had to provide the vocabulary knowledge, text structure and language feature knowledge about descriptive text, and local-content knowledge. In addition, paper-based reading materials were appropriate to be implemented in the classroom. To provide interesting materials, illustrations or pictures were also included alongside reading texts. 


\section{Students' Reading Level}

The last analysis was to find out the students' reading level. Starks Informal Reading Assessment (Starks, 1981) was given to the students which included reading texts at levels $1,2,3,4$, and 5 . The results of this test were described as follow:

Table 2. The Distribution of students' Reading Level

\begin{tabular}{llll}
\hline TEXT & Reading Stage & & \\
\cline { 2 - 4 } LEVEL & Frustrational & Instructional & Independent \\
& $($ CorrectNumber $=\leq 6)$ & $($ Correct Number $=7-8)$ & (Correct Number 9-
\end{tabular}

10)

\begin{tabular}{lllllll}
\hline & NOS* & $\%$ & NOS* & $\%$ & NOS* & $\%$ \\
\hline Level 1 & 5 & $16 \%$ & 21 & $70 \%$ & 4 & $13 \%$ \\
\hline Level 2 & 7 & $23 \%$ & 23 & $76 \%$ & 0 & $0 \%$ \\
\hline Level 3 & 3 & $10 \%$ & 26 & $86 \%$ & 1 & $3 \%$ \\
\hline Level 4 & 25 & $83 \%$ & 3 & $10 \%$ & 2 & $6 \%$ \\
\hline Level 5 & 28 & $93 \%$ & 2 & $6 \%$ & 0 & $0 \%$ \\
\hline *NOS= Number of Students & & &
\end{tabular}

Source: Modified from Merrit William Starks (1981)

The result above showed that students were already at the instructional stage (70\% of 30 students) for text in level 1 . For text in Level 2, students were at the instructional stage (76\%). Then text in level 3 , students were at the instructional stage (86\%). While for text in levels 4 and 5, students were at frustration stages which were $83 \%$ and $93 \%$ subsequently. It can be seen from the results that students' reading level was at level 3 as the biggest percentage of students who belonged to the instructional level was at level 3. Therefore, since the students' reading level was at level 3 , the reading materials which were developed were level $1,2,3,4,5$ which means there were 2 levels below and 2 levels above the students' reading level included into the reading materials.

\section{Design Phase}

In this phase, writing the learning objectives was firstly conducted which had been identified in the analysis phase. The next step was collecting all the information about traditional clothes and tourism places in Sekayu. Then, that information was arranged and wrote into some passages with 10 kinds of traditional clothes and tourism places in the forms of reading materials and 5 reading comprehension tests. Next, the readability levels of the developed descriptive texts for reading comprehension tests were checked by using an online tool of Flesch Kincaid (i.e.: https://readability-score.com/).

There were five descriptive texts for the reading comprehension test that had different readability levels. In line with what was suggested by the writer's advisors, reading comprehension test had to have 1 text which exactly matched with the students' reading level, 2 texts which had to be 2 levels above the students 'reading level, and 2 texts which had to be 2 levels below the students' reading 
level. As the students' reading level was at level 3, the readability levels of the stories had to be at level 1, 2, 3, 4, and 5 .

In the reading materials, there were ten descriptive texts, entitled IkanSalai, Pundang, Pedeh, Ulak Lia, Bekarang, GamboMuba, Permata Park, Sekayu Waterfront, Selarai Indah Park, and DanauKonger. Each descriptive text was completed by the pictures and the reading exercises as well. The exercises were arranged in various types of questions; those were multiple-choice questions and true-false items and used as a formative evaluation of the lesson whether the students achieved the learning objectives or not. Meanwhile, there were ten developed reading comprehension tests. The texts were followed by 40 multiple-choice questions which consisted of reading comprehension aspects; those are main ideas, details, inferences, sequences, cause and effects, references, and vocabularies. All of the items were constructed based on the indicators which had been created in the analysis phase.

\section{Evaluation and Revision}

\section{Self-Evaluation}

In this phase, the product was constructed in which those are about the reading materials descriptive text by considering the results of the students' reading level and needs analysis. The layout of the cover was designed such as the words and pictures. Then, the developed product was reread along with revising some misspelling, and punctuation before it was given to the experts for reviewing. Expert Review

In this phase, there were two experts evaluated the developed instructional reading materials with a local culture-based descriptive text in terms of content and construct validity. In terms of content validity (i.e.: English), the expert reviewer was an English lecturer at Sriwijaya University. After reviewing the product, she stated that the product was valid with revision. Moreover, from the validation sheet, there were some comments related to some parts which had to be revised such as the grammar in the reading text and the form of questions.

In terms of construct validity (i.e.: instructional design), the expert reviewer was an English lecturer at Sriwijaya University and well known of her expertise in instructional design. After reviewing the product, she stated that the product was valid with revision. From the validation sheet, the expert only comment "Go on! Only minor revision such as the grammar in the reading text. By considering her comments, the writer, then, changed or redesigned the developed product based on what was suggested.

The result of the validity level of the product shown that in terms of content, the average score was 2.73 (High Validity). Then, in terms of construct, the average score was 3.13 which fell in the "High Validity" category. Moreover, the average score of two experts' validation sheets was calculated to determine its overall validity which was 2.93 falling in the "High Validity" category. Therefore, it can be concluded that the developed instructional reading materials with Sekayu local culture-based descriptive texts were valid and in very high validity category. 


\section{One-to-One Evaluation}

In this phase, there were three students were involved consisted of one student as a representative from each category (i.e.: high, medium, and low English proficiency which were selected based on the students' English score). The students were given the developed reading materials, and then they evaluated those materials to determine its practicality through the questionnaire. Moreover, to determine the overall practicality of the developed reading materials with Sekayu local culture-based, the students' average score of the questionnaire was calculated and then interpreted into practicality categorization. Based on the results of the questionnaire from the total 15 items of the questionnaire, the average score from the three students' scores was 3.48 which fell at a very high practicality level. It can be concluded that the developed reading materials with Sekayu local culture-based descriptive texts were practical and at a very high practicality level.

In addition to the questionnaire, the writer also provided the column for the students to give their comments on the developed reading materials with Sekayu local culture-based descriptive text. The results of their comments that they felt happy and understood more after studying these reading materials, but they also hoped that the time allocation should be sufficient. However, the developed reading materials containing Sekayu local culture based descriptive text were appropriate to the eighth grade students since those were practical to be implemented.

Small-Group Evaluation

In this study, small group evaluation involved nine students of the eighthgrade students consisted of three students as representatives from each category (i.e.: high, medium, and low English proficiency). Students who were the participants in the one-to-one evaluation were not involved anymore in this phase. The students were given the developed reading materials and they were then given the questionnaire after studying to know the practicality of the developed reading materials with Sekayu local culture-based descriptive texts. Moreover, to determine the overall practicality of the developed reading materials, the students' average score of the questionnaire was calculated and then interpreted into practicality categorization. Based on the results of the questionnaire from the total 15 items of the questionnaire, the average score from the nine students' scores was 3.50 which were in the 'very high' category. It can be concluded that the developed reading materials with local content-based descriptive texts were practical and at a very high practicality level.

In addition to the questionnaire, the writer also provided the column for the students to give their comments on the developed reading materials with local content-based descriptive text. The results of students' comments in small group evaluations were most students said that they like the reading materials since it is easy to understand. Similar to one to one evaluation, the results of the developed reading materials after being evaluated were practical to be used, so those were appropriate for the eighth grade students which were at level 3. 
Field Test

The purpose of the field test was to know the effectiveness of the developed reading comprehension test with local culture-based. The field test involved a real class of the eighth-grade students of consisting of 16 students. The students who were selected in one-to-one and small group evaluations were not involved anymore in this field test. In this phase, the students were given developed reading comprehension tests in the form of 40 multiple choice questions which covers 7 aspects of reading such as main ideas, details, inferences, cause and effects, sequences, references, and vocabularies.

The writer firstly measured the reliability of the developed reading comprehension test by using Alpha Cronbach. The result of the correlation coefficient was .909. Moreover, the writer measured the validity of the test by using the Pearson Product Moment. The result of items validity showed that there were 6 items $(5,9,11,12$, and 33$)$ of the reading test categorized as invalid questions. Three of them are about detail questions and the rests are about inference questions. However, the writer also measured the difficulty index and discrimination index. According to Heaton (1989, p. 23), the index of difficulty of an item simply reflects how easy of difficulty the particular item proved in the test. The result of the difficulty index showed that all items in the developed reading test felt in medium criterion in which there were 29 items out of 40 items. Regarding that theory, thus, it was concluded that all items of developed test were appropriate (neither too easy nor too difficult) for the students. Then, based on the results of discrimination index, there were 9 items in developed test felt in moderate category and there were 24 items felt in good category. According to Heaton (1989, p. 23), discrimination index measures how well the test items were arranged to identify the differences in the student's competence. Based on the results all items in developed reading comprehension tests were considered having good criterion either in terms of its difficulty index or discrimination index.

Furthermore, the writer correlated the result of the reading comprehension test and standardized test developed by Starks Jr (Starks, 1981) through Pearson Product Moment Correlation Coefficient to see the effectiveness of developed reading comprehension test. It was done by the SPSS (Statistical Package for the Social Science) computer program version 22. The result of the correlation coefficient was 0.82 . According to Evans (1996), the absolute value of $r$ in range $0.80-1$ is a very strong positive correlation. It means that the two sets of scores have a very strong level of agreement.

Moreover, the writer also compared partially the scores of each reading aspects (categorized as literal, inferential, and vocabulary) in the reading comprehension test to which included in the reading level test by using Pearson Product Moment. The result of coefficients of each aspect showed strong correlation which was 0.69 (literal), 0.56 (inferential) and 0.40 (vocabulary). In this developed reading materials, main ideas and details belonged to literal, cause and effect, sequence, and inference belonged to inferential, while reference and vocabulary belonged to vocabulary. 
Finally, the writer analyzed the reading comprehension tests by checking the students' correct answer. The reading comprehension test could be categorized as effective because there were 12 students (76.38\%) out of 18 students in the reading comprehension test reached the minimum mastery criterion which was 70 . Based on the results, the developed reading materials containing Sekayu local culture descriptive text were effective to be implemented in the classroom as an instructional material for teaching and learning process for the eighth grade students which were at level 3.

\section{CONCLUSION}

From the results discussed previously, there are some conclusions drawn. Firstly, the developed instructional reading materials with Sekayu local culturebased descriptive texts were valid in terms of its content (English) and construct (instructional design) after being evaluated by two experts. Secondly, the developed reading materials with Sekayu local culture-based descriptive texts were very highly practical after being evaluated in one-to-one and small group evaluation. The last, the reading assessment which was given in field test also could be categorized as effective since there were 12 students (76.38\%) out of 18 students reached the minimum mastery criterion which was 70 . Therefore, the developed products containing Sekayu local culture descriptive texts were totally suitable to be used for the eighth grade students since the results of the developed products after being evaluated were valid, practical, and effective.

\section{REFERENCES}

Akker, J. (1999). Principle and methods of development research. In J. Akker, R. Branch, K. Gustalfon, T. Nieveen N, \&Plomp (Eds.), Design methodology and development research (pp. 1-14). London, UK: Kluwer.

Alay, S., \&Koçak, S. (2003). Relationship between time management and academic achievement of university students. Theory and Practice of Educational Management Magazine, 326-335.

Alyousef, H. S. (2006). Teaching reading comprehension to ESL/EFL learners. Journal of Language and Learning, 5(2), 63-73.

Broek, P., \&Espin, C. A. (2012). Connecting cognitive theory and assessment: Measuring individual differences in reading comprehension. School Psychology Review, 41(3), 315-325.

Chen, S. C., \& Chen, K. T. (2015). The use of EFL reading strategies among high school students in Taiwan. The Reading Matrix, 15(2), 156-166.

Davoudi, M., \&Yousefi, D. (2015). Comprehension breakdown: A review of research on EFL learners' reading difficulty and problems. International Journal of Language and Applied Linguistics, 1, 58-72.

Diem,. D. (2012). How the presence of a technologically supported library influences high school students' reading habits and skills.Global Advanced ResearchJournal of Library, Information and Archival Studies, 1(1), 1-5

Education First. (2017). EF English proficiency index. Retrieved from https://www.ef.com/__ /media/centralefcom/epi/downloads/fullreports/v7/ef-epi-2017-english.pdf 
Emilia, E., \& Christie, F. (2013). Factual genres in English: Learning to write, read, and talk about factual information. Bandung, Indonesia: Rizqi Press.

Elviana, R., Inderawati, R., \&Mirizon, S. (2020). Developing interactive multimedia for teaching descriptive texts based on palembang local culture. Indonesian EFL Journal (IEFLJ). (6), 19-26

Evans, J. D. (1996). Straight forward statistics for the behavioral sciences. Pasific Grove, CA: Brooks/Cole Publishing.

Firmanto, S. O. (2005). Students behavior of reading comprehension: Expectations and follow up. Paper presented at the LIA International conference, Jakarta.

Fitriani, S. S. (2014). An investigation into reading comprehension strategies in academic texts in Aceh Province of Indonesia. The Third International Conference on Language Education 2013 (ICOLE 3), 95-126.

Heaton, J. B. (1989). Writing English language test. New York, NY: Longman Group UK limited.

Kasim, U., \&Raisha, S. (2017). EFL students' reading comprehension problems: Linguistic and non-linguistic complexities. English Education Journal (EEJ), 8(3), 308-321.

Kirkpatrick, A. (2008). Teaching English across cultures. What do English language teachers need to know how to teach English.EA Journal, 23(2).

Kubiszyn, T., \&Borich, G. (1993). Educational testing and measurement: Classroom application and practice (4th ed). New York, NY: Harper Collins College Publisher

Malone, S. (2013). Resource for developing graded reading materials for mother tongue-based education. http://bit.ly/1PQGVM3

Masduqi, H. (2014). EFL reading in Indonesian universities: perspectives and challenges in cultural contexts. Journal of Teaching and Education, 3(3), 385397

Monica, S. (2016). Developing local content-based instructional graded reading materials for reading level three students [Master, UniversitasSriwijaya] Palembang, Indonesia.

OECD. (2018). PISA 2015 results in focus. Retrieved from https://www.oecd.org/pisa/pisa-2015-results-in-focus.pdf

Peterson, S., \&Ostendorf, M. (2006). Assessing the reading level of web pages. In Proceedings of Inter speech 2006 (poster), pages 833-836

Pitaloka, N. L. (2014). Developing interactive multimedia with local-content based narrative texts for eight grade students [Master, UniversitasSriwijaya] Palembang, Indonesia.

Prado, L., \&Plourde, L. (2005). Increasing reading comprehension through the explicit teaching of reading strategies: Is there a difference among the genders?Reading Improvement, 32-43.

Presnyakova, I. (2011). Systemic functional analysis of elementary school language arts textbooks [Master, Marshall University]. Huntington, West Virginia

Rahman, H. (2004). An Evaluation of the Teaching of Reading Skills of English in Bangladesh [Master, University of Rajshahi]. Rajshahi, Bangladesh. 
Rukmini, D. (2004). Genre analysis of the reading texts in the English text book for for high school students published by Balai Pustaka. Paper presented at The 52nd TEFLIN International Conference, Palembang.

Samad, I. A., Jannah, M., \&Fitriani, S. S. (2017). EFL students' strategies dealing with common difficulties in TOEFL reading comprehension section. International Journal of Language Education, 1(1), 29-36.

Sari, M. T. (2016). Developing local Content-Based Instructional Descriptive Reading Materials for Reading Level Three Students. [Master, UniversitasSriwijaya], Palembang.

Stark, M. W. (1981). A group informal reading inventory: An instrument for the assessment of ESL students' reading performance. http://bit.ly/183SDUW

Sopian., Inderawati, R., \& Petrus, I. (2019). Developing e-learning based localfolklores for eighth graders. English Review: Journal of English Education, (8), 101-112

Tessmer, M. (1993). Planning and conducting formative evaluation. Philadehelphia, PA: Kogan Page

Yovanoff, P., Duesbery, L., Alonzo, J., \& Tindal, G. (2005). Grade-level invariance of a theoretical causal structure predicting reading comprehension with vocabulary and oral reading fluency. Educational Measurement: Issues and Practice, 24(3), 4-12. 